north fork of the Shenandoah near Strasburg, on the evening of the 12 th. Here we remained until the $I 5$ th, when it becoming evident that Early would not give us fight in that position, we fell back to near Charlestown, arriving there on the 18th. Here. Gen. Grover came up with reinforcements from Washington and a reorganization took place. The $24^{\text {th }}$ 'was assigned to the $4^{\text {th }}$ Brigade, 2d Division, I9th Army Corps, Col. D. Shunk, 8th Ind. Vet. Vols., commanding brigade, Gen. Grover commanding: 2d Division, and Brevet Maj.Gen. Emory commanding igth A. C.

The. Army of the Shenandoah now consisted of two divisions of the Igth A. C., Gen. Emory commanding - the 6th Corps, Maj.-Gen. Wright commanding, the Army of Western Virginia commanded by Gen. Crook, and about I0,00o cavalry commanded by Gen. Torbert-in all about 40,000 under command of Maj.-Gen. Sheridan. Remaining at Charlestown until the 2 Ist, the army moved to Bolivar Heights, between Halltown and Harper's Ferry, and entrenched. On the 28 th it was moved out about two miles southwest of Charlestown, where it entrenched. There we mustered for pay on September $\mathrm{I}$.

NoTE--Mr. Smith's history of the Twenty-fourth Iowa Infantry ends here. He did not live to complete it. There is, however, a continuation of the history of the regiment in the report of Gen. Ed Wright to the Adjutant General of: Iowa, in 1865 . This, with possibly other data, will be presented in an early number of THE ANNALS, completing the narrative down to the close of the war.

\title{
WHO WROTE THE POEM "THERE IS NO DEATH"?
}

A letter from the Author, J. L. MCCrefery, an Iowa man.

DeAR SIR: I am in receipt of your request that I furnish you a full account of the origin of the verses beginning, "There is no Death"; of the circumstances that led to their being ascribed to Sir Edward Bulwer Lytton; and of the reasons of my making certain changes therein upon republishing them in the little volume of my poems entitled, "Songs of Toil and Triumph." 
Not foreseeing the notoriety that was destined to attach to these verses, I did not mark down in my diary (if I kept one) the exact date when I wrote them. The nearest I can come to it is to say, that it was in February or March of 1863 . I was at that time a resident of Delaware county, Iowa. One pleasant Saturday afternoon I was riding from the northwestern part of the county, by way of Forestiville and Manchester, to my home at the then county seat-Delhi. My (borrowed) horse could go no faster than a walk, the most of the way, as the last of the winter's snow was thawing from the ground, and the roads were very muddy: 'so the journey, of about twenty miles, was not finished until after dark.

My early education had all been with a view to the (Methodist) ministry; St. Paul and John Wesley were the unapproachable heroes of my boyhood-and I have lost none of my admiration for them yet. 'But I had become skeptical. regarding many points of dogma regarded as essential by orthodox churches. My riental and moral make-up was such that I could not preach what I did not believe; and I did not recog-: mize in myself any special fitriess for any other calling. True, I was editor and proprietor of a weekly newspaper, The Dela-: avare Connty Journal, but the prospect was that the mortgage I had given for the purchase money of the office would be foreclosed in a few months; it was doubtful what sort of farmer I would make, and it was certain that it would be a long time before I could earn money enough to buy a farm ; and my muscular development was not such as to warrant me success in sawing wood. In short, I was, as respects a purpose in this life or a theory of my destiny in another, adrift without chart or compass upon a boundless sea of uncertainty. The fundamental question ás to whether there was any such thing as a personal existence hereafter was one upon which I was bestowing most serious consideration. True, I had read what Emerson says: "Concerning immortality the soul, when properly employed, is incurious." But I had not reached the Emersoniam altitude of altruism. "With the question as to' personal immortality settled in the affirmative, I felt that pretty 
much everything else, in this world or any other, would take care of itself.

I was yet half a dozen miles from home when nightfall overtook me, and the stars began to shine out, one after another. The splendid constellation Orion, the brighest visible in our northern latitudes, was just past his meridian, riding in triumph down the western sky. The subdued and tranquil radiance of the "heavenly host" relieved the somberness of my meditations, and imparted a more serene and hopeful tinge to my thoughts and feelings. Just at this juncture the first four lines of the poen came to me in their completeness. I say "came to me" as the most nearly appropriate manner of expressing the fact that the first I knew I found them in my. mind. I certainly had not the least idea of setting myself at work to makea poem for the occasion. It would be equally incorrect to say that I ". heard a voice", uttering the words in my bodily or spiritual ear.

By this time it was between nine and ten o'clock; I had reached my home; and the duties of practical everyday lifeoccupied my.attention to the exclusion of all imaginative or poetical ideas.

The next morning I sat myself about making some more of that poem. But I labored-I use the word advisedly-I labored at a disadvantage. The exalted and imaginative mood' of the evening before had vanished. The "inspiration," though earnestly invoked, refused to inspire. But in the course of the forenoon I constructed, in a mechanical sort of a way, several more verses, and laid them aside for a while, to dry.

I was at that time taking "Arthur's Home Magasine," of Philadelphia. It had previously printed three or four of my contributions. It gratified my vanity more to have an articleprinted in a down-east magazine than to print it myself, in my own paper; it showed that some one else thought it worth placing before the public. So, sometime in the spring of that year, I sent my verses to Arthur's Home Magazine. In the course of three or four months they appeared-in the num- 
Who IVROTE THE POEM "THERE IS NO DEATH"?
ber for July, I 863 (Vol. 22, page 4I). The following is the form in which they at first appeared:

There is no death : the stars go down.

To rise upon some other shore;

And bright in heaven's jeweled crown

They shine for evermore.

Thers is no death : the dust we tread

Shall change, beneath the summer showers,

To golden grain, or mellow fruit,

Or rainbow-tinted flowers.

The granite rocks disorganize

To feed the hungry moss they bear ;

The forest leaves drink daily life

From out the viewless air.

There is no death : the leaves may fall,

The flowers may fade and pass away;

They only wait, through wint'ry hours,

The coming of the May.

There is no death: an angel form

Walks o'er the earth with silent tread;

$\mathrm{He}$ bears our best-loved things away, Atid then we call them dead.

He leaves our hearts all desolate, He plucks our fairest, sweetest flowers ;

Transplanted into bliss, they now Adorn immortal bowers.

The bird-like voice, whose joyous tones Made glad this scene of sin and strife,

Sings now its everlasting song Amid the tree of life.

Where'er he sees a smile too bright Or soul too pure for taint of vice,

$\mathrm{He}$ bears it to that world of light, To dwell in Paradise.

Born into that undying life, They leave us but to come again :

With joy we welcome them, the same Except in sin and pain.

And ever near us, though unseen,

The dear, immortal spirits tread;

For all the boundless universe

Is life:-there are no dead!

A week or two after they had been printed in the Home Magazine I reprinted them in the Delaware County Journalgiving credit to the Home Magazine.

The second branch of your inquiry is, how the verses came to be attributed to Lord Lytton?

I learned the printer's trade, while yet in my teens, in the 
office of the Telegraph, at Dixon, Illinois. My earliest and greenest literary productions were printed in that paper. The foreman of the printing office was named John H. Moore; my best friend when I was a homeless, destitute, and but for him, friendless boy. When I printed my verses in the Delazvare County Journal I sent him a marked copy. -I am not certain but by that time he had become employed upon another paper in Dixon; you must remember that at that time I was not expecting to go down to posterity very, far, and did not charge my mind with all sorts of unimportant little 'fact ts and dates. At any rate, whatever paper he wäs working" on', he had in part (in the absence of the editor) the selecting of reprint copy. And he printed my verses in that paper.

South of Dixon, somewhere in Illinois (I have forgotten the exact locality), there lived somebody by the name of Eugene Bulmer-or else he took that for a'pseudonym; I have never known to a certainty which. He wrote an article for the Farmers' Advocate, an agricultural paper then pubiished in Chicago. For some reason, undoubtedly satisfactory: to himself, instead of writing on the silver question, the subtreasury scheme, the cause of the low price of corn, or the best method of dehorning cattle, he essayed a more modest role, and one requiring less information on the part of the writer, and indited a column and a half on the subject of "Immortality." His article concluded with my verses. The Fariners' Adviciate exchanged with the Dixon paper; my friend. Moore saw this article, and sent the paper to me-at the same time informing me that he had written to the Farmers' Advocate setting me right in the matter.

But it was too late. A Wisconsin paper that exchanged with the Farmers' Advocate cut off the poetry part of the article on Immortality, and pinted it, with the name attached, "E. Bulmer." The abbreviation of the first name was obviously the result of the laziness of the compositor: Then another Wisconsin paper printed it, just to fill up with, and either the editor or the compositor; sagely supposing that he had discovered a typographical error in the name, changed the 
" $\mathrm{m}$ " to a " $w$," and the work was done! "E. Bulwer" was now of record as the author of a poem that the distinguished Lord Edward Bulwer Lytton, of England, had never seen nor heard of.

I never saw these Wisconsin papers. It was a long time afterward before I learned of "these facts.' Then, being in Chicago one day, I called at the office of 'the'Farmers' Advo: cate. The editor afforded me an interview of half or threequarters of an hour; in the course of which he furnished me the information embodied in the last preceding paragraph; but after the lapse of years he could not give me the names of the papers-the whole affair being but an incidental and, very minor matter in his busy life.

Meanwhile the poem has encircled the world!! I have re:ceived papers containing it printed in nearly every state of the Union; in England, Scotland; Ireland; Wales and Canada; and even one from Australia. "It has gone into dozens of school books, and been incorporated in scores of miscellaneous collections of poetry. It has been quoted, in full or in part, five times, that I know of, in Congress; on the last day of January, I880, I had the pleasure of sitting in the strangers' gallery of the House of Representatives, in 'Washington, $\mathrm{D}$ '. C., and hearing the Hon. Mr. Coffroth, nimemer of Congress from Pennsylvania, in his oration on the death of the. Hon: Rush Clark, member of Congress from 'Iowa, quote a' portion of it (credited to Lord Lytton, as usual), which thus became embalmed in the Congressional Record. (See 46 th Congress; $2 \mathrm{~d}$ session, part I, page 638 .)

About I 870, Harper Brothers, of New'York city; publishers of school books (among other things), printed the verses in their United States Fifth Reader, page 242 -crediting them to Lord I_ytton. My attention was directed to the fact by' $\mathrm{Mr}$ : John Kennedy, in his earlier years of Delaware county, Iowa', who afterward became agent for these publishers. 'He sug: gested that it would be well for me to present evidence suffcient to convince the firm that I was the author of the verses, and he would do the best he could to have the credit changed 
from Bulwer to myself. I furnished the evidence, and he brought the matter to the attention of the publishers. About a year later he wrote me as follows:

Franklin Square, N. Y., March 27, 1875.

Friend McCreery :--I send you herewith a page of the table of contents of one of our school readers, in which you will find the poem accredited to you. 'The plates have recently been changed. This is an advance sheet. As soon as the books are out I will send you a copy. You have no idea of the amount of form through which such a question of change has to pass.

From that time until the present, every year or two the question has been publicly raised by some leading newspaper or magazine; but all who have taken the pains to make a thorough investigation have arrived at the same result. A few years ago Lippincott's Magazine (Philadelphia) printed "One Hundred Questions" regarding disputed literary matters, offering a prize to the person who should answer the greatest number of them. Question No. 80 was in regard to the authorship of this poem; answers were made implicating, as usual, Lord Lytton and myself; and the Magazine decided (June, I889, pages 918-9), that I was the author. In the Iowa Masonic Annual Souvenir for I890-1, Hon. T. S. Parvin, Grand Librarian for Iowa, printed the verses, over my name; for this he was taken to task by the Masonic Tyler of Detroit; this led Mr. Parvin to make an exhaustive investigation, which confirmed him in his original opinion. The editor of the Tyler, however, remained obstinate and refused to be converted, until, when he directly challenged me personally to prove my claim, I wrote to him offering him a thousand dollars if he would produce the verses, or any of them, written by Lord Lytton or any one else, printed in any book, magazine, newspaper, or in any other shape, prior to their publication under my name in Arthur's Home Magazine, for July, 1863; thereupon, in the Tyler for April 15, I 893, he acknowledged that he had been misled. The thousand-dollar argument is not a very dignified one, but it has thus far proved effective.

Finally, you ask me to explain how it has come about that there are different versions of the poem afloat. 
Some of these changes have been made by the publishers of the different volumes in which it has appeared. Thuswhere I originally wrote, in the first verse, "The stars go down. to rise upon some other shore," Messrs. Ivison, Blakeman, Taylor \& Co., in their "American Educational Reader, No. 5,"page $32 \mathrm{I}$, changed it to "some fairer shore"; and made half a dozen other changes of equally slight importance. The greatest changes, however, have been made by myself.

In the summer of $\mathrm{I} 883$ I received a proposition from Putnam's Sons, of New York city, relative to publishing some of the poetry. I had written up to that time. At their suggestion: I separated the serious and sentimental from the humorous, leaving the former in their hands, to an amount that they estimated they could afford to print and sell at retail for one dollar. These they printed in a neatly bound volume of a little over 1.5.0 pages, under the title, "Songs, of Toil and Triumph." A feiw years later I "bought in" so much of the edition as remained unsold, and thus acquired a library of several hundred volumes.

In preparing this little work for publication, I carefully re-vised every poem printed therein; among them the one now under consideration. During the twenty years since it was. written I have matured (somewhat) in judgment; and the more the public, bewildered by the glamour of Bulwer's name attached to it, saw surpassing beauties in it, the more glaring in my own eyes became its defects. For instance, the lines. originally written

$$
\begin{aligned}
& \text { "The granite rocks disorganize } \\
& \text { To feed the hungry moss they bear," }
\end{aligned}
$$

seemed to intimate, by negation, that other kinds of rock, except granite, do not disorganize. To say the least, "granite" was surplusage; and every needless word weakens a sentence. So I remodeled the verse by dropping the "granite."

The last couplet of the same verse,

"The forest leaves drink daily life

From out the yiewless air,

was very awkward. In the last line, "out" was worse than " 
surplusage. It may have been good Greek idiom, as shown in Matthew, $7^{\text {th }}$ chapter, 5th verse: "First cast out the beam out of thine own eye; then shalt thou see clearly to cast out the mote out of thy brother's eye"; but certainly it was not good English. Both sense and leuphony demanded that I cast out the "out" out from out of that sentence; and I settled the matter by casting out the verse.

Again, in the couplet that at first said of the flowers,

"They only wait, through wintry hours, The coming of the May,"

it was manifest to the dullest comprehension that "the" was forced in before "May" simply to fill out the meter. It was as inappropriate as it would be to assert that Independence day is celebrated on the: "Fourth of the July." So I gave that line a twist that would in part rectify its awkwardness :

"The warm, sweet breath of May."

Again, in the verse,

"Where he sees a smile too bright

* * * * for taint of vice,

$\mathrm{He}$ bears it to that world of light,

To dwell in paradise,"

the simile, or metaphor, or whatever syntactical figure of speech it may be, did" not delight me when I came to look at it critically. I tried to imagine how "he" (whoever "he" was) went at it to bear away that "smile." Possibly he ran a pole through it and carried it off on his shoulder. Possibly. he folded it up flat and packed it in his valise. I inclined to the latter hypothesis, for the longer I listened to it with my mental ear, the flatter it sounded. I decided to omit that verse.

\footnotetext{
"The birdlike voice, whose joyous tones

Made glad this scene of sin and strife, Now sings its everlasting song

Amid the tree of life,"
}

:is not, I frankly confess, wholly original. So far as the rhyme is concerned, while I concede that "life" might -be made to rhyme with "rife," or "wife," or "knife," or in a pinch even with "fife," I do not remember that I have ever seen it rhymed "with anything except "strife." And I have seen it rhymed so 
often during the thirty years that have elapsed since I wrote the poem, that. I have become as tired of it as the man is reported to have become of quail, after having eaten a quail a day for thirty days. My impression is that even before I * wrote that verse somebody had rhymed "life". with "strife." Therefore I wish to be understood as distinctly disclaiming any originality as to the rhyme. As to the idea before writing that verse I had listened to a funeral sermon in which the preacher asserted that the deceased sister, who had formerly been a soprano singer in the church choir, was now singing the song of the redeemed beside the river of life, I could not work into the poem anything about the "river of life," on. account of the meter; but I got along very well by making use of the "tree of life." Then, the meter and the "woman" would not agree; besides I had my doubts as to whether "poetic license" would allow me to represent a "woman" up. a tree. So I put the "voice" in the tree: "vox et preterea nilitl." But, as intimated above, I am free to confess that I do not build my hopes of literary immortality on the surpassing ingenuity manifested in making "life" rhyme with "strife," or in getting a voice "amid" a tree. So I took out the "tree."

The verse,

" Born into that uncying life,

They leave us but to come again ;

With joy we welcome them-the same

Except in sin and pain,"

is ambiguous, because of the elision in the last line, rendered: necessary by the exigencies of the meter. It might mean, as easily as anything, that when they return they are the same as when they left, "except" (that they return) "in sin and pain." Besides, the statement carries with it a suggestion of materiality and coarseness that is unpoetic, unspiritual, and not in accordance with my actual thought. It appears to me that there is much more delicacy and elegance in the verse as reconstructed.

"We feel upon our fevered brow

Their gentle touch, their breath of balm," etc.

Perhaps too much ought not to be expected of poetry, in: 
the way of common sense and logic; yet certainly if it purports to enforce any given lesson, and is apparently written for that especial purpose, it would seem that it ought not forth-

- with to proceed to argue something directly the contrary. But while I start out to assert that " there is no death," I proceed to state that the rocks-do what? continue in existence forever? On the contrary, quite the reverse; they disorganize, they become moss, but never again rock-certainly not that identical rock. The forest leaves drink life from the air; in autumn they fade and pass away; do those leaves that fade and pass away come up fresh and blooming with the coming of the ensuing May, or is it some other leaves that succeed those that have perished? If these illustrations illustrate anything, they illustrate precisely the opposite hypothesis from that for which I called them into being; for if I do what the rock does, what the leaf and flower do, what the bird and its voice do, I shall disintegrate, perish as an individuality, and be transmuted by the forces of nature into something else. In the light of reason and common sense, what is there admirable in the logic or illustrations of a poem which succeeds in enforcing a lesson directly contrary from that which its author intended?

I know you will excuse me from going over each verse seriatim, and explaining just why it was unsatisfactory to me. Suffice it to say that to obviate so far as possible some of the objections I have mentioned (and others that I have not mentioned), I altered some of the verses; some I entirely omitted; and $I$ added several, with the purpose of making the thought more connected and coherent than it originally was. There seems to me to be a little more sense, a little less absurdity, and just as much poetry, in the version as printed in "Songs of Toil and Triumph":

There is no death! the stars go down

To rise upon some other shore,

And bright in heaven's jeweled crown

They shine for evermore.

There is no death! the forest leaves

Convert to life the viewless air ;

The rocks disorganize to feed

The hungry moss they bear. 
There is no death! the dust we tread

Shall change, beneath the summer showers,

To golden grain, or mellow fruit, Or rainbow-tinted flowers.

There is no; death! the Jeaves may fall;

The flowers may fade and pass away-

They only wait, through wintry hours, The warm, sweet breath of May.

There is no death! the choicest gifts 'That heaven hath kindly'lent' to earth

Are ever first to seek again

The country of their birth.

And all things that for growth or joy Are worthy of our love or care,

Whose loss has left us desolate, Are safely garnered there.

Though life hecome a dreary waste, We know its fairest, sweetest flowers,

Transplanted into paradise, Adorn immortal bowers.

The voice of bird-like melody

That we have missed and mourned so long

Now mingles with the angel choir

In everlasting song.

There is no death ! although we grieve

W'hen beautiful, familiar torms

That we have learned to love are torn

From our embracing arms.

Although with bowed and breaking heart,

With sable garb and silent tread,

We bear their senseless dust to rest, And say that they are "dead."

"They are not dead! they have but passed Beyond the mists that blind us here

Into the new and larger life

Of that serener sphere.

They have but dropped their robe of clay

To put their shining raiment on ;

They have not wandered far away-

They are not " lost " nor "gone."

Though disenthralled and glorified,

They still are here, and love us yet;

The dear ones they have left behind

They never can forget.

And sometimes, when our hearts grow faint Amid temptations fierce and deep,

.Or when the wildly raging waves

Of grief or passion sweep,

We feel upon our fevered brow

Their gentle touch, their breath of balm;

-Their arms enfold us, and our hearts

Grow comforted and calm. 
And ever near us, though unseen,

The dear, immortal spirits tread;

For all the boundless universe

Is life :-there are no dead.

I have answered your questions; but will add one or two. more facts, which you may print or omit, as you choose. This little poem has. had considerable influence on my career. In the fall of 1868 , shortly after General Grant's election to the Presidency, he returned to his former home in Galena, Illinois. I was not at that date reclining upon a bed of roses, metaphorically speaking or otherwise ; and at my suggestion a friend of mine in Galena, in high position, conferred with the President elect in regard to the possibility of my obtaining the appointment of his official stenographer when he should enter upon his duties at the White House. My friend was so enthusiastic in his advocacy of my merits that the General showed unmistakable indications of being disposed to make the appointment-in case upon trial I should be found competent. But in a moment of indiscretion my friend said a little too much. As a "clincher" to his highly-colored account of my literary abilities, he pulled from his pocket a copy of "There is No Death," and read it to Gen. Grant. When he had 'finished he looked up into the General's face, and at once saw that he had.blundered. The General said the poetry was very good-no doubt-he did not pretend to be a judge of poetry; when he became President, what he should need about him were men who understood public business, and whose minds would be on their business; and so far as his experience and observation went, a man that was good at making poetry generally was not good for much of anything else. I was not appointed official stenographer to the President. What my life thereafter would have been if my friend had not read that poem to him it is impossible to conjecture.

But it has influenced my career in another and widely different manner. The tendency has been to do away with all ambition to write poetry for the public--an ambition that I acknowledge I cherished in my early days. The "Songs of 
Toil and Triumph" contain a number of poems written in early life, before my literary ambition waned; and a number of more recent date, pertaining to purely personal and family matters ; but for the last quarter of a century I have written nothing for the public.

Washington, D. C., Aug. 15,1893 .

J. L. McCreEry.

\section{CHIEF JUSTICE CALEB BALDWIN.}

BY EX-CHIEF. JUSTICE GEORGE G. WRIGHT.

Among the best and warmest friends I have ever had, personally, professionally, politically and officially, was the strong, able and true man whose name heads this article. He was from Pennsylvania, born in that county (Washington). which has sent out so many grand men to the West and the Nation, and a graduate of that school (Washington College) which has given as much, if: not-more, good and educated brains to the world than any institution East or West: In college with such men as Blaine and others of national reputation, he was ever admired by his old schoolmates, and none others rejoiced more in his successes and triumphs. From such a locality; he was naturally; by influence and association, a Presbyterian: A brief epitome of his life, private and public, would. be this:

Born April 3, I $8 \dot{2}_{4}$; graduated in I 842 ; moved to Iowa in 1846 , and was married to Jane Barr at Fairfield in 1848 . To this union there were born eleven .children; six now living: Laura, Lizzie (now Mrs. W. S. Ament, of Denver), Thomas, John N., Susan (now Mrs. Jason Walker, of Kentucky) and Janie. He was Prosecuting Attorney of Jefferson county for three successive terms-in 1856 was appointed Judge of the District Court by Governor Grimes, to fill a vacancy occasioned by the resignation of Hon. W. H. Seevers--moved to Council Bluffs in 18.57 , and in 1859 was elected to the Supreme Court of Iowa, at the first election under the present Constitutionin 1862 , became Chief Justice; declining a re-election, he re- 
Copyright of Annals of Iowa is the property of State of Iowa, by \& through the State Historical Society of Iowa and its content may not be copied or emailed to multiple sites or posted to a listserv without the copyright holder's express written permission. However, users may print, download, or email articles for individual use. 